\title{
Somatosensory Receptor
}

National Cancer Institute

\section{Source}

National Cancer Institute. Somatosensory Receptor. NCI Thesaurus. Code C13819.

Nerve endings encased in connective tissue capsules with myelinated or unmyelinated axons. 